\title{
Communications
}

\section{Barbituric Acid Derivatives as Protein Tyrosine Phosphatase Inhibitors}

\author{
Bhooshan Kafle, ${ }^{a}$ Bharat Raj Bhattarai, ${ }^{a, b}$ and Hyeongjin Cho* \\ Department of Chemistry and Institute of Molecular Cell Biology, Inha University, Incheon 402-751 Korea \\ ${ }^{*}$ E-mail: hcho@inha.ac.kr \\ Received October 18, 2010, Accepted October 25, 2010
}

Key Words: Barbituric acid, Protein tyrosine phosphatase, Inhibitor, PTP1B

Barbiturates infer derivatives of barbituric acid. Commonly used barbiturates like phenobarbital and secobarbital have substituents at the 5 position on this basic skeleton. Barbiturates slow down central nervous system (CNS) functions and have been used to treat medical conditions such as epileptic seizures and as anesthesia for surgical procedures. ${ }^{1}$ Beside the effects as CNS depressants, barbiturates have been shown to exhibit wide variety of other biological activities, including anti-tumor activities, immuno-modulating activities, herbicidal or insecticidal activities, PPAR $\gamma$ agonistic activities, and inhibitory activities against mucosal addressin cell adhesion molecule-1 interactions. ${ }^{2-6}$ Notably, barbiturates, including phenobarbital and secobarbital, were also found to inhibit the phosphatase activity of calcineurin, a protein Ser/Thr phosphatase. ${ }^{7}$ In view of this observation, we considered the barbituric acid moiety as a candidate scaffold for the design of protein tyrosine phosphatase (PTP) inhibitors.

PTPs, together with protein tyrosine kinases, are key regulators of the phosphorylation of proteins involved in cellular signal transduction pathways. The importance of the regulated protein phosphorylation is evidenced by the recognition of a wide variety of diseases accompanied by the disturbances in the phosphorylation states of cellular proteins. Suggested as a strategy

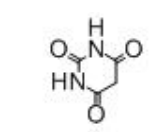

Barbituric acid

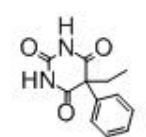

Phenobarbital

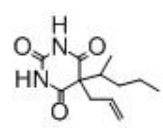

Secobarbital

Figure 1. Barbituric acid and its derivatives used as CNS depressants.

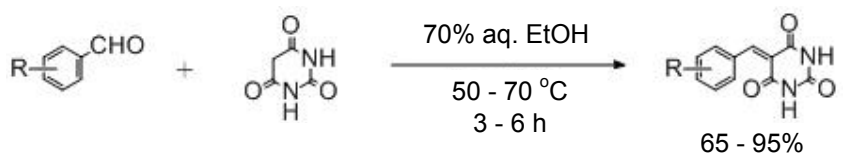

Scheme 1. Synthetic strategy for the synthesis of barbituric acid derivatives

${ }^{\mathrm{a}}$ These authors contributed equally to this work.

${ }^{\mathrm{b}}$ Current address: Department of Chemistry, University of Connecticut, 55 North Eagleville Road, Storrs, CT 06269, U.S.A.

${ }^{*}$ Corresponding Author Address: Department of Chemistry, College of Natural Sciences, Inha University, 253 Yonghyun-dong, Nam-ku, Incheon 402-751, Korea. for the treatment of such diseases, inhibition of PTPs constitutes a major theme of medicinal chemistry as well as of this study. ${ }^{8}$

In this study, barbituric acid derivatives were synthesized by condensation of appropriate benzaldehyde derivatives and barbituric acid with minor modifications of a reported procedure (Scheme 1). ${ }^{9}$ The desired products were obtained in $>90 \%$ yields except a few cases where the yields were $65-80 \%$. The benzaldehyde derivatives for the synthesis were purchased or prepared as shown in Scheme 2.

The barbituric acid derivatives were assayed for their inhibitory activity against PTP1B, a human PTP. Among those,
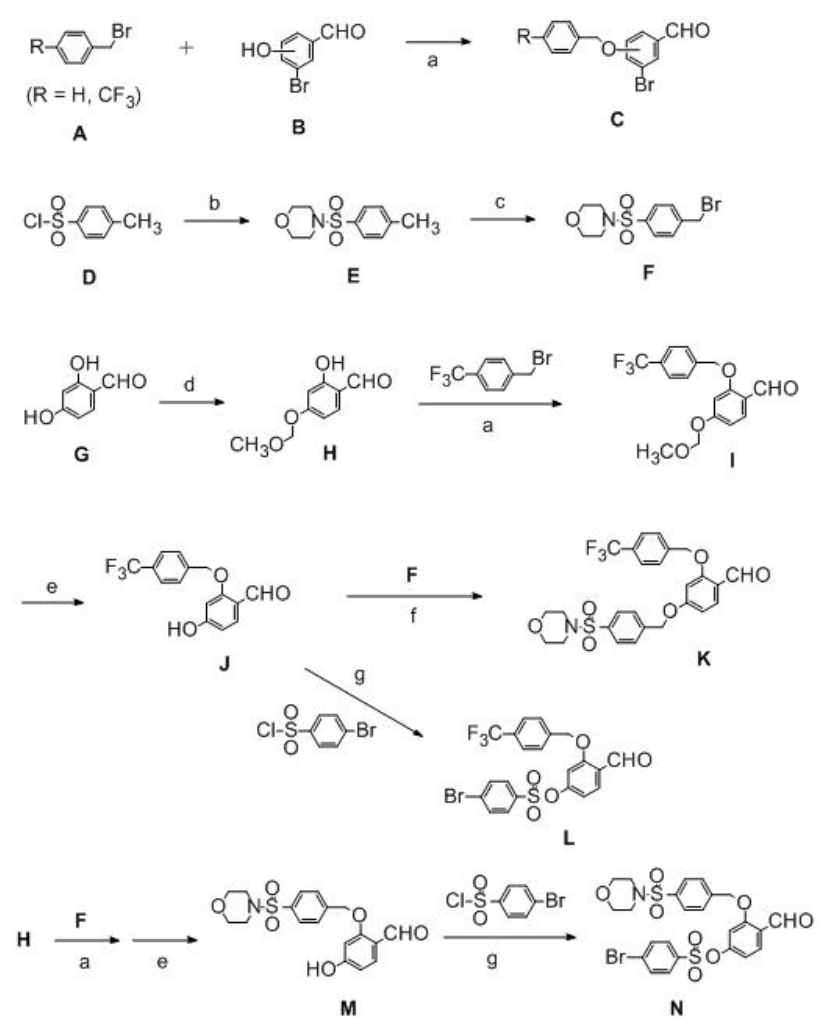

Scheme 2. Synthesis of benzaldehyde derivatives. Reagents and conditions: (a) $\mathrm{K}_{2} \mathrm{CO}_{3}$, DMF, rt, $1-4 \mathrm{~h},>85 \%$, (b) morpholine, $\mathrm{Et}_{3} \mathrm{~N}$, THF, rt, 3 h, $95 \%$, (c) N-bromosuccinimide, $\mathrm{CCl}_{4}$, reflux, 4 h, $56 \%$, (d) $\mathrm{CH}_{3} \mathrm{OCH}_{2} \mathrm{Cl}, \mathrm{K}_{2} \mathrm{CO}_{3}$, acetone, $0^{\circ} \mathrm{C} \rightarrow \mathrm{rt}, 4 \mathrm{~h}, 53 \%$, (e) $6 \mathrm{M} \mathrm{HCl}$, THF, $50{ }^{\circ} \mathrm{C}, 2 \mathrm{~h},>80 \%$, (f) $\mathrm{K}_{2} \mathrm{CO}_{3}$, acetone, reflux, $2 \mathrm{~h}, 68 \%$, (g) $N, N$ diisopropylethylamine, DMF, $0{ }^{\circ} \mathrm{C} \rightarrow \mathrm{rt}, 2 \mathrm{~h},>95 \%$ 
Table 1. Inhibitory activity of the barbituric acid derivatives against PTP1B

\begin{tabular}{|c|c|c|c|c|}
\hline Compounds & $\mathrm{R}^{1}$ & $\mathrm{R}^{2}$ & $\mathrm{R}^{3}$ & $\mathrm{IC}_{50}(\mu \mathrm{M})^{a}$ \\
\hline 1 & & $\mathrm{H}$ & $\mathrm{Br}$ & $340 \pm 30$ \\
\hline 2 & $\mathrm{H}$ & & $\mathrm{Br}$ & $200 \pm 10$ \\
\hline 3 & $\mathrm{H}$ & & $\mathrm{Br}$ & $47 \pm 2$ \\
\hline 4 & & & $\mathrm{H}$ & $10 \pm 1$ \\
\hline 5 & & & $\mathrm{H}$ & $27 \pm 2$ \\
\hline 6 & & & $\mathrm{H}$ & $44 \pm 3$ \\
\hline 7 & $\mathrm{H}$ & $\mathrm{OH}$ & $\mathrm{OCH}_{3}$ & $>1000$ \\
\hline 8 & & & $\mathrm{H}$ & $27 \pm 3$ \\
\hline 9 & & & $\mathrm{H}$ & $52 \pm 2$ \\
\hline 10 & & $\mathrm{H}$ & $\mathrm{Br}$ & $88 \pm 15$ \\
\hline
\end{tabular}

${ }^{a}$ Values are the mean \pm standard deviations of two or more experiments. PTP1B assay was performed as previously described using $p$-nitrophenyl phosphate $(p \mathrm{NPP})$ as the substrate. ${ }^{10} \mathrm{IC}_{50}$ values were determined by measuring the $p$ NPP hydrolase activity in a range of different inhibitor concentrations. Kinetic data were analyzed using GraFit 5.0 program (Erithacus Software).

Table 2. Inhibition of PTP1B and other PTPs by compound $\mathbf{4}^{a}$

\begin{tabular}{cccc}
\hline \multirow{2}{*}{ Compound } & \multicolumn{3}{c}{$\mathrm{IC}_{50}(\mu \mathrm{M})^{b}$} \\
\cline { 2 - 4 } & PTP1B & YPTP1 & YOP \\
\hline 4 & $10 \pm 1$ & $12 \pm 1$ & $15 \pm 1$
\end{tabular}

${ }^{a}$ YPTP1 were expressed in $E$. coli expression systems and purified as previously described. ${ }^{10} \mathrm{YOP}$ was purchased from New England Biolabs, Inc. (Beverly, MA, U.S.A.). The assay condition was the same for all PTPs except the enzyme concentrations, which were $40 \mathrm{nM}$ for PTP1B, $15 \mathrm{nM}$ for YPTP1 and 50 units (manufacturer's definition) $/ \mathrm{mL}$ for YOP. ${ }^{b}$ Values are mean \pm standard deviations of two or more experiments.

compound $\mathbf{4}$ with trifluoromethylbenzyloxy substituents at both $\mathrm{R}^{1}$ and $\mathrm{R}^{2}$ was proved most potent with an $\mathrm{IC}_{50}$ value of $10 \mu \mathrm{M}$ (Table 1). The inhibitory activity of 4 was also evaluated against two other PTPs, YPTP1 and YOP (Table 2). YPTP1 is from Saccharomyces cerevisiae and YOP is the Yop51 gene product of Yersinia enterocolitica, that contains the C235R mutation (Yop51*). Compound 4 exhibited similar inhibitory potencies against all three PTPs.

To investigate the mode of inhibition, steady-state kinetic experiments of PTP1B and YPTP1 were performed for compound 4 . The mode of inhibition was determined by the Lineweaver-Burk plot analysis of the results of the kinetic experiments (Figure 2). The compound 4 inhibited PTP1B and YPTP1 in a noncompetitive and a mixed-type noncompetitive fashion, respectively. These results indicate that the binding site for the compound $\mathbf{4}$ is different from that for the substrate. The noncompetitive inhibition of PTP1B might be explained by the posible binding of the barbituric acid moiety in the secondary aryl (a)

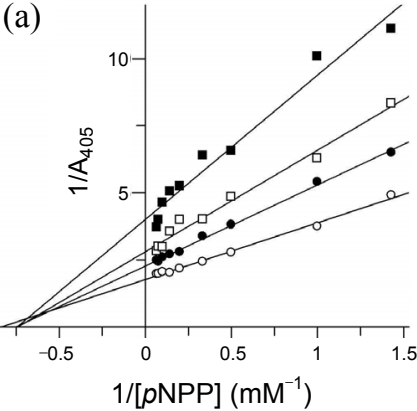

(b)

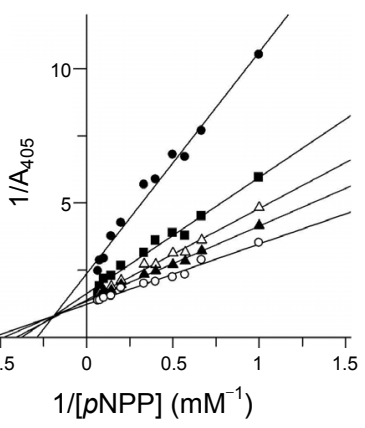

Figure 2. Lineweaver-Burk plot analysis. Phosphatase activity was measured against $p$ NPP for (a) PTP1B in the presence of $50 \mu \mathrm{M}(\mathbf{\square})$, $40 \mu \mathrm{M}(\square), 30 \mu \mathrm{M}(\bullet)$ or none ( $(\circ)$ of compound 4 and (b) YPTP1 in the presence of $35 \mu \mathrm{M}(\bullet), 25 \mu \mathrm{M}(\bullet), 20 \mu \mathrm{M}(\Delta), 15 \mu \mathrm{M}(\boldsymbol{\Delta})$ or none (०) of compound 4

phosphate-binding site, present near the active site of PTP1B. ${ }^{11}$ On the other hand, the mixed-type noncompetitive inhibition of YPTP1 by 4 could hardly be explained on the same basis, because no aryl phosphate-binding site distinct from the active site has been identified on YPTP1. Nondiscriminative inhibition of the three structurally diverse PTPs by 4 also implicates the possible similarity of the inhibitor binding sites on these PTPs. Explanation of these apparently conflicting observations and considerations requires additional studies including X-ray crystallographic structure determination of the enzyme-inhibitor complex. Enzyme-inhibitor interaction yet to be explained at the molecular level, the barbiturate moiety was proven to be a promising scaffold for the design of PTP inhibitors.

Acknowledgments. This study was supported by a grant from Inha University. B. R. Bhattarai and B. Kafle were recipients of BK21 fellowship.

\section{References}

1. López-Muñoz, F.; Ucha-Udabe, R.; Alamo, C. Neuropsychiatric Disease and Treatment 2005, 1, 329.

2. Jursic, B. S.; Neumann, D. M.; Bowdy, K. L.; Stevens, E. D. J. Heterocyclic Chem. 2004, 41, 233 and references cited there in.

3. Driscoll, J. S.; Melnick, N. R.; Quinn, F. R.; Lomax, N.; Davignon, J. P.; Ing, R.; Abbott, B. J.; Congleton, G.; Dudeck, L. Cancer Treat. Rep. 1978, 62, 45.

4. Brewer, A. D.; Minatelli, J. A.; Plowman, J.; Paull, K. D.; Narayaman, V. L. Biochem. Pharmacol. 1985, 34, 2047.

5. Sundriyal, S.; Viswanad, B,; Ramarao, P.; Chakraborti, A. K.; Bharatam, P. V. Bioorg. Med. Chem. Lett. 2008, 18, 4959.

6. Harriman, G. C.; Brewer, M.; Bennett, R.; Kuhn, C.; Bazin, M.; Larosa, G.; Skerker, P.; Cochran, N.; Gallant, D.; Baxter, D.; Picarella, D.; Jaffee, B.; Luly, J. R.; Briskin, M. J. Bioorg. Med. Chem. Lett. 2008, 18, 2509.

7. Humar, M.; Pischke, S. E.; Loop, T.; Hoetzel, A.; Schmidt, R.; Klaas, C.; Pahl, H. L.; Geiger, K. K.; Pannen, B. H. J. Mol. Pharmacol. 2004, 65, 350 .

8. Vintonyak, V. V.; Antonchick, A. P.; Rauh, D.; Waldmann, H. Curr. Opin. Chem. Biol. 2009, 13, 272.

9. Brückmann, G.; Isaacs, S. D. J. Am. Chem. Soc. 1949, 71, 390.

10. Shrestha, S.; Bhattarai, B. R.; Kafle, B.; Lee, K.-H.; Cho, H. Bioorg. Med. Chem. 2008, 16, 8643.

11. Puius, Y. A.; Zhao, Y.; Sullivan, M.; Lawrence, D. S.; Almo, S. C.; Zhang, Z.-Y. Proc. Natl. Acad. Sci. USA 1997, 94, 13420. 